\title{
The Quintessential Naqqashi Nirmal Painting Art of Telangana: Source of Inspiration for Innovative Textile Design Ideas
}

\author{
Challa Lakshmi* and Manisha Gahlot \\ Department of Clothing and Textiles, College of Home Science, G.B. Pant University of \\ Agriculture and Technology, Pantnagar, Udham Singh Nagar, Uttarakhand, India \\ *Corresponding author
}

\begin{abstract}
A B S T R A C T
Keywords

Hand painting,

Naqquashi, quintessence,

Tempora, Deccani style, Nirmal arts

Article Info

Accepted:

10 July 2020

Available Online:

10 August 2020

Hand painting is an ancient quintessence of workmanship rehearsed from centuries old. The main reason for people adoring paintings is that often hues remain as pictorial memories in our senses. The Deccani sultanates in Peninsular India patronized this Naqqashi craftsmanship from sixteenth century. The study was planned with objectives of documenting the origin and development of this beautiful wood based Nirmal art in Telangana state and to adapt these motifs on textile products. The data regarding the history and current status of the art was collected from the purposively selected artisans practicing this art till to date. Tempora technique of hand painting was practiced by these artisans in which natural colouring materials were used on the base prepared from the local forest based Ponniki wood. The art has not undergone much alternations and modifications over the period with reference to the motifs used, tools, techniques employed and production processes involved. In turn it has given a flexible opportunity for new modern designing concepts and ideas along with retention of traditional ethics and values.
\end{abstract}

\section{Introduction}

Each and every region of India is famous for its unique, distinctive culture, traditions and heritage. Naqqash community of craftsmen from Telangana produced pictures from Hindu epics like Ramayana, Mahabharata. Telangana is a rich land with wide array of fascinating art forms, unique in style, concept, expression and theme. The present study is a descriptive and exploratory method of research. The purpose of this study is to document the origin, history, motifs, techniques employed in traditional Nirmal arts and crafts. It further opens a new platform for revitalizing a languishing craft and for developing a base for creation of new products with added value. Very few research studies have been carried out in this regard; hence the current research study is initiated to understand and improvise on the current status of Nirmal painting industry.

\section{Materials and Methods}

The selected places for the present research study were Hyderabad in Ranga Reddy District and Nirmal city in Nirmal district of 
the newly formed Telangana state (erstwhile Adilabad district of United Andhra Pradesh). The selection of the sample was based on the inhabitation of the Nirmal artists in these places. A total of fifty currently available artisans out of whom, thirty people were residing in Nirmal city and twenty people who were also from Nirmal and surrounding places but were relocated in Hyderabad for various reasons were chosen for the study. Inferential approach was used to collect primary and secondary sources of information. Surveys by means of personal interviews, checklists and questionnaires, observations were effectively used as a primary source of data collection. The secondary sources that were available online and offline were utilized for the data collection.

The data was initially collected by observation method. Every single detail of the painting process was observed and noted down for documentation purpose. The raw materials used, motifs employed, colours used were keenly observed and noted down. The information was collected from the local people, leaders, Nirmal art lovers and artisans through interview technique. Each individual was interviewed about the awareness, technical know-how and religious and cultural significance and personal preferences for this enchanting Nirmal art.

\section{The origin and evolution of Nirmal paintings art}

The origin of Nirmal art and craft can be traced back to fourteenth century during the reign of Kakatiya dynasty. It was started with limited range of products like paintings for pooja, wall paintings, panels and partitions. The principle articles prepared were based on characters from mythological, religious epics along with folk narratives. The artisans created portraits of life size that resembled as real, lively with exuberant looks and extraordinary presentations. The Nirmal artisans often sought to dramatize and recreate the different personalities from epics, narratives, folklores and stories that were widely accepted by the kings, royal families along with common people with same passion and intensity. These paintings were created with the use of natural pigment paints and dye extracts on the surface of walls and wood. Later from sixteenth century onwards, the Deccani sultanates in Peninsular India cherished and patronized this Naqqashi craftmanship. The word "Naqqashi" was born from telugu language word "Nagishi" meaning ornamental, variegated sculpture art (telugudictionary.org, 2020) ${ }^{[17]}$.

Nirmal town in the Northern part of Telangana state shares its unique, legendary identity in the arena of local as well as global arts and crafts. Naqqash also refers to those community of craftsmen living in Nirmal place. Nirmal town is located amidst the dense forests of the newly created Nirmal district (erstwhile Adilabad District) in Telangana. It is believed that Naqqashi families and Jhingar artists were brought to Nirmal place from Rajasthan during 17th Century by Nimma Naidu, a local khiladar and leader (Venkateswarlu,2015) ${ }^{[12]}$. The name "Nimmala" was given by Nimma Naidu which was later modified as Nirmal in the due course of time. This town is quite famous for the Nirmal toys, paintings and furniture. The artisans have imbibed this art of lacquered woodwork painting style from their forefathers and the same is being now practiced from times immemorial. The Naqqashi Nirmal style of painting is a delicate and highly integrated blend of indigenous and foreign artistically expressive craft forms. During the Mughal Era, emperor was extremely enchanted by their art form. In 17th Century, as per local legend (Imperial Gazetteers of India Adilabad-Nizamabad and 
Karimnagar, 1908) ${ }^{[5][16]}$. The Nizam of Hyderabad visited the Nirmal village, where he was warmly welcomed by the artisans. They created intricately designed bud of banana and placed spectacular golden petals inside the bud. This was placed at the royal seat and when Nizam opened the bud he was showered red by the golden petals. Highly impressed with this, the Nizam began patronizing the artists and their crafts. The credit for popularizing the Nirmal art among the common people goes to Lady Hyder Ali, who brought the artisans to Hyderabad, five centuries ago(Dadiga, 2017) ${ }^{[2]}$. The motifs used are inspired from frescos of Ellora and Ajantha, Kangra and Mughal miniature paintings, Floral and faunal designs. The art utilizes indigenous colours from herbs, gems and minerals. Soft wood called Ponniki strengthened with different coats of pip clay, fine muslin and tamarind seed paste is utilized for base. Initially the artists created mythological figure and took inspiration from nature in creating birds, animals and trees (2009-2010 report, Development Commissioner-Handicrafts, Southern Regional Office, Chennai) ${ }^{[5][7]}$. A unique feature of this Nirmal art is that the basic techniques did not change much over the years. Currently it is facing a bleak situation as the artists are giving up their ancestral profession and seeking other alternatives for their livelihood. This has occurred over a period of time where demand for Nirmal art work started to decrease. In recent times, it is facing threats from the modern digitized and automized printing methods.

\section{Raw materials used in Nirmal painting art}

The artisans have inherited this skill of paining art that is put into practice from generations. The three main aspects that go into the making of these paintings were basewood, design and color.

\section{Base or background surface}

Wood of the "thella poliki", "ponika" or "ponnikki" (words in telugu) of the tree (Govotia rottleriformis synonym ofGivotia moluccana (L.) Sreem) was utilized for making Nirmal articles. It is a dioecious tree growing up to 20 meters height with bark in brown colour with smooth texture, peeling off in thick scales. It is more soft, pliable and flexible compared to the wood derived from other conventional trees. The plant belongs to the family Euphorbiaceae, commonly called as white Catamaram tree grown in central and peninsular Indian forests. The wood can be used for carving figures, toys, etc. The seeds produce valuable lubricating oil used for fine machineries. Its conservation status is NE (not evaluated) category (indiabiodiversity.org, $2020)^{[18]}$. The poniki wood gives the artisans an added advantage of making a range of paintings and toys from this lightweight wood.

\section{Design development process}

Design development is designated as continuous, ongoing and evolutionary process that results in new concepts. Many motifs used in the Nirmal paintings were collected during documentation of the Nirmal art and craft industry. Few of the popular designs used are presented as follows:

\section{Source for colours}

The colours are naturally derived from pigments of herbs, vegetables, fruits and mineral deposits. The colours employed in the Nirmal art are basically vegetable, earth, lake pigments, metallic. Vegetable pigments are obtained from plant sources, earth pigments from different areas of coloured earth soil and stones, lake pigments are the stone deposits that are stagnant and flowing in the water bodies that are collected and used for colours. 
Metallic deposits like gold, silver, copper and bronze are used along with other fixing materials for decoration of the paintings. These pigments are used in combination with binders, gums, fixers and other natural mordants. Lake colours basically dry slowly. Hence for lake colours that are dark are mixed with linseed oil and the lighter ones with poppy seeds and nut oils like clove, almonds, etc. Each individual pigment has its own recipe formulations for desired tints and shades of the hues. Choice of pigment depends on season along with type and nature of pigment and its source. The selected pigments are treated either with different oils or by gums or in conjunction with metallic compounds or driers to hasten their drying time. Sometimes independent or combination of liquids like honey, sugar, molasses, starch, glycerin was also utilized in few instances (Isacco and Darrah, 1993) ${ }^{[8]}$.

The major colours used are given in the following table:

The Tamarindus indica (tamarind tree) plays a significant role in giving shape to the broken or damaged edges of the frames and aids in colour fixation through seeds and gum respectively. The leguminous tree belongs to family fabaceae. The pod like fruit gives a sweet, tangy fleshy, juicy acidic pulp that is used in cuisine along with medicinal uses. It chemically consists of tartaric acid, glucose, calcium. Tamarind kernel powder is having excellent water absorption and high viscosity and binding properties (Thombare et al, 2014)

${ }^{[11]}$. It is used as thickening agent in sizing process for textiles. It is also used as metal polish.

\section{Tools used for painting}

These include tracing papers, dot pins, colour mixing palettes, drawing pencils, erasers, tracing chalk powder, pigment grinding plate and stone or muller, water for mixing. Brushes of broad width, filling brushes, fine brushes of different sizes were used for this painting work. Fine details were painted using brushes made from animal hair. Fine brushes made from squirrel's hair were highly preferred due to their precision. Finest brushes made from single hair strand were employed for finer lines and outlining. Apart from these palm leaves, tamarind tree twigs, bird feathers, bamboo twigs were also used in painting. The gum of the tamarind seeds along with gum Arabica was used as water soluble gum resist for outlining the drawings. These line help in spreading the paint to the unwanted areas of the painting.

\section{Technique of Naqqashi Nirmal painting}

\section{Preparation of the base}

The traditional process begins with the raw wood from Ponniki tree being cut into desired blocks and sizes. The frame sizes in inches that are commonly used were $8 \times 11,12$ X17, $17 \mathrm{X} 24.30 \mathrm{X} 24$, Wood cutting machine in the saw mill is used to cut the big blocks into small pieces. Specially prepared lye, "chinta lappam", which is prepared from ponniki wood sawdust powder that is obtained as waste during cutting the main frames, boiled liquid obtained from tamarind seeds powder mixed in water and then the resultant liquid is mixed with white or pipe clay to the desired consistency. The solution thus derived is colochially called as "chintha lappam" or "lye". The frame is then strengthened with different coats of this lappam to smoothens any ridges and depressions and give smooth finish to the base (Plate 15 to 17). The Ponniki wood dust powder is used to rub on the surface of the board to make it smooth. This chintha lappam absorbs the moisture from the wood and helps the wood to last for long time. 


\section{Preparation of the background colour}

The background colours used for the Nirmal art include black, white, red, brown. The prominent colour for background used was black in major occasions. After applying luppam, black paint is coated for the background. The frame is cleaned linseed or cotton seed oil is varnished to give a glossy surface.

\section{Naqqashi work of tracing}

The typical and distinguishing feature Nirmal Painting is the sketching process of the chosen design. The design is drawn or traced from the main source to transparent drawing sheet or a fine muslin cloth. The sheet is perforated with tiny holes along the lines of the design and on the entire outline of the figure with a safety pin or dot pins. The holes facilitate the chalk powder to pass through them during copying stage of the design transfer from paper to wood. The design is transferred into the target base with the help of chalk powder. Later the impressions are joined with a pen to retain the design till the work is completed. Later the marks will get wiped off in the subsequent stages. Originally parchment paper or fine muslin cloth was used for drawing and tracing purpose. Later these got replaced by drawing and tracing sheets (Venkateswarlu, 2015) ${ }^{[12]}$.

\section{Coloring the paintings}

These paintings were executed in the traditional tempera technique (Silva, 1971) ${ }^{[10]}$. It is a technique in which the pigment is held together with water solution mixed with fixers and binders. This method is the oldest and probably used from first century Ad and still continues to exist (Wikipedia, 2020) ${ }^{[13]}$. After mixing the colours in water along with a binding and fixing medium they were applied on the drawing. Once the tracing of design is complete, filling of the major and broad areas is done as per the chosen shade plans. The finer details are worked out with more intricacy and patience. The body parts, garments, flesh areas are done first in case of human figurines. The face and hair areas are worked out separately with more care. In the final stage of painting, the work is given a special look with application of metallic colours done with gold, silver, copper and bronze. This gives the Nirmal paintings distinctive appearance of bejeweled and rich look for the characters that make this art more lively and vivid.

Few colours originally used in Nirmal were very distinctive such as earthy browns, bottle greens, glowing reds and often striking blacks and yellows besides golden hues used to embellish mythological figures and scenes from the epics. These colours gave a specialized and distinctive feature for these master creative art works. (Development Commissioner -Handicrafts, Ministry of Textiles, 2001) ${ }^{[4][3]}$.

\section{Motifs used}

The motifs in use during 14th to 16th century was drawn from historical and mythological narratives and were purely art objects. These include idols of King, Queen, Minister, Natraj, Laxmi, Saraswathi, Hanuman, Maha lakshmi, Mangala harathulu, Gopala Krishna, Radha Krishna, Santhoshi matha, Gondu goddess, Dandi maramma, Vaddera Amma, Sagada Parvathi, Yellamma, Pochamma, Nagaraja and many more Government of Andhra Pradesh, Director of handcrafts and handlooms textile report, 1985) ${ }^{[3]}$. The seventeenth century saw a new horizon of this art form. The designs adopted by the Nirmal workers are mostly traditional and derived from different sources Ajanta Frescoes, temple friezes, art schools, Persian art, Nizam art, Mughal paintings, Kangra and Pahari 
miniature paintings, Raja Ravi Verma paintings, folk, mythological characters, ancient forts, historical monuments, Ganjfa playing cards, etc (Refer Plates 1 to 14). The collected motifs were classified into various theme categories based on source of inspiration and method of usage by the researcher. The theme categories are mentioned as follows:

Mythological: Motifs that were created based on mythological stories like Ramayana (Rama, Sita, Lakhmana, Hanuma), Pattabhishekam, Seethapaharna, Jathayu vimochanam, Life saviour-AnjaneyaSanjeevini, Bhagavadgitha(Krishna, Arjuna, subhadra), Geethopadesam, Rukmini kalyanam, Mahabharatam and the war scenes, Ganjfa card designs, etc

Religious: Ganesha, Shiva-Parvathi, Balaji, Govindam. Venkatesa charitam, Ayyappa swamy, Sai Baba, Veera Bala Ayyappan, Maa Shakthi, Durga, Bhavani, Lakshmi devi, Mohini avatar, Mother Earth, Fire as god, Lord Krishna, Radha-Krishna, Rukmini Kalyanam, Brindavanam, Gopika Krishna, Different religious symbols, etc.

Historical: Royal forts, temples, palaces, Inspirations from Ajantha and Ellora caves, Kangra and Miniature paintings, Ajantha school art works, Gauthama Budha, NalaDamayathi, Royal court scenes, Nizam, Nawab and Deccani styles, Portraits of rulers, kings, popular personalities like Ashoka Chakravarthy, Sri Krishna Devaraya, Kakathiya, Cholas at different historical timelines, Popular female characters like Shakunthala, Menaka-Viswamitra,

Musical and dance oriented: Veena, drums, guitar, flute, Kolatam dance, dancing couples, Ekthara, Sitara, Bharathanatyam. Kuchipudi, Odyssi dance, Mohini attam,
Folk art: Emotional aspects of human beings like joy, happiness, sadness, love, passion, romance, waiting period, separation anxiety, stories like Panchatantra, entertainment-based motifs, Banjaran motifs, Nizam style figurines, rangoli patterns, village and rural life settings, etc

Wedding theme: This category includes organizing and conducting marriage, pre and post preparations, mandap set up, procession of groom and bride, other rituals and ceremonies associated with it.

Inspirational arts: Eminent artists like Raja Ravi Verma Seetha vanvas, Hamsa Damayanthi Samvad, Priyadarshika, Padmini, Vasanthasena, Shakunthala-Sakhi, YashodaKrishna, Mohini, Woman holding fruit, etc.

Sceneries: Nature, waterfalls, sky in different shade, water, rivers, oceans, waterfalls,

Nature: Beautiful creations of mother earth, flora, fauna and beautiful locations, etc

Floral Designs: flowers, twigs, creepers, fruits, leaf motifs, trees, plants, vegetables, etc

Birds and animal: elephant, swan, koyal, peacock, cow, parrot, deer, etc

Contemporary: Stylized and modified versions of the traditional motifs, modern art, etc (Refer plates 18 and 19)

Customized: Motifs created on the consumer requirements, personal preferences, etc

Finishing and presentation of the completed Nirmal painting art work

In the final stage, the paintings are given a varnish coating for colour fixation and surface protection. Thus, it is a long tedious and time taking process that takes a minimum period of 
three to four weeks for single naqqashi artist to work on small sized painting frame. This process requires the greatest level of imagination by an artisan. Popular items made include portraits, wall panels, paintings, screens for partitions, boxes for jewellary, Ganjfa boxes with playing cards and food tray covers.

\section{Nirmal art current status}

The traditional Nirmal art paintings were created originally with the use of plant based natural pigment paints and dye extracts on the surface of walls and Ponniki wood. The Ponniki wood got replaced by other forms like seasoned teak-wood, rose-wood and artificial and plywood cardboard frames. Later with the passage of time, the natural paints were replaced by synthetic or nitrocellulose paints, duco colours, acrylic colours, oil paints, etc. Similarly, chinthalappam was replaced by the chemical NC Putti or lappam putti for the base preparation. Artificial gums, binders and varnishes were used in place of natural gums and binders. In recent years, efforts are made to revive these paintings by the use of vegetable colours, eco-friendly dyes and paints, taking the advantage of the hereditary traditional techniques. The motifs and designs often consist of mythological, historic, natural, floral, birds, animals, beautiful sceneries, marriage processions and functions, royal, rural, folk and country lifestyle. Many designs and motifs from different regions and crafts gained place in this art. In this process, Nirmal art-work underwent some material changes and deviations from its original structure.In 1955, co-operative society was established in the Nirmal village. Various artisans were promoted in this art. Many new comers and interested people are also selected and trained in this art. Few of the artists were even awarded by the State level, national level master craftsmen awards and other recognitions. Popular Nirmal Artists who contributed significantly to this art for a long time include Eruva Anantha Rao who was credited with many awards and rewards at different national and international levels, Thota Laxmi Narayana, Nampalli Rajasekhar, Bhusani Bhaskara Varma, Padma Rao Varma, Narsingam Racharla Lambaiah who got National master craftsmen award for 1990 from President Gyani Jail Singh, N. Rajasekhara Varma has won state award for his outstanding craftsmanship and contribution for Nirmal arts in 2014, Rajendra Kumar Naqqash, senior Nirmal artist who is imparting training to the younger generation through Shilparamam, a craft village in Hyderabad.

\section{Results and Discussion}

Very few records pertaining to the origin of Nirmal craft exist till date. Nirmal town in the Northern part of Telangana state shares its unique, legendary identity in the arena of local as well as global arts and crafts. Many royal dynasties, Hindu kings, Moghuls, Nizams and Nawabs, governmental and nongovernmental agencies, associations, entrpreneurs have patronized and promoted this Naqqashi Nirmal craftmanship from fourteenth to the present twenty first century. Initially the artists created mythological figure and took inspiration from nature in creating birds, animals and trees (2009-2010 report, Development Commissioner-Handicrafts, Southern Regional Office, Chennai) ${ }^{[7]}$.

A unique feature of this Nirmal art is that the basic techniques did not change much over the years. Currently it is facing a bleak situation. As a result of decrease in sales and demands, increased problems in terms of working conditions, the artists are giving up their ancestral profession and seeking other alternatives for their livelihood. The feeling of the ability to earn better than those earned in 
this Nirmal art is growing on a daily basis. The younger generation is not giving much interest in this work as lot of patience, skill, time and persistence are required for the Nirmal painting art. No passion is expressed in continuing the hereditary basedand skill oriented naqqashi Nirmal art works. Today in the modern world, Nirmal art is also facing challenges from the automized digital printing works, the natural raw working materials required for this painting works have become scarce and expensive due to lack of available suppliers in sufficient quantities (Rao, 2012)

Table.1.Colours used in Nirmal art

\begin{tabular}{|c|c|c|}
\hline SI No. & Hue & Component used \\
\hline 1. & white & Indian tin oxide, calcium white, Lime stone, Lead white \\
\hline 2. & Black & kaolin, qasim solution of kalamkari, ivory, almond \\
\hline 3. & Indigo blue & Indigo stones/ leaves \\
\hline 4. & Flesh colour & burnt amber or sienna \\
\hline 5. & The Indian Red & $\begin{array}{l}\text { Alizarin, Sappan wood, Ratanjoth, vermilion mixed with } \\
\text { china clay base }\end{array}$ \\
\hline 6. & Yellow & red ochre, clay, turmeric, safflower \\
\hline
\end{tabular}

\section{Plate.1}

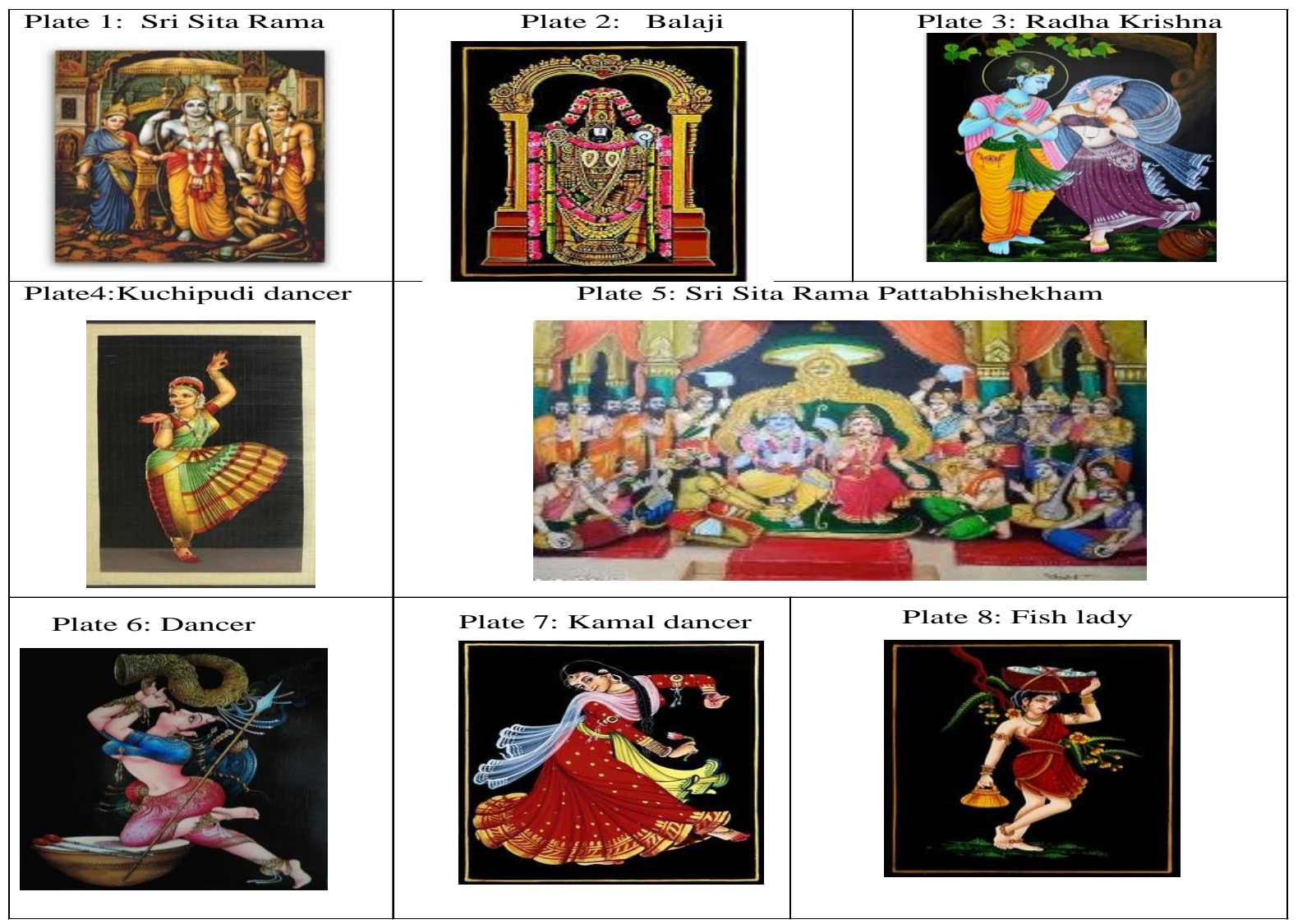




\section{Plate.2}

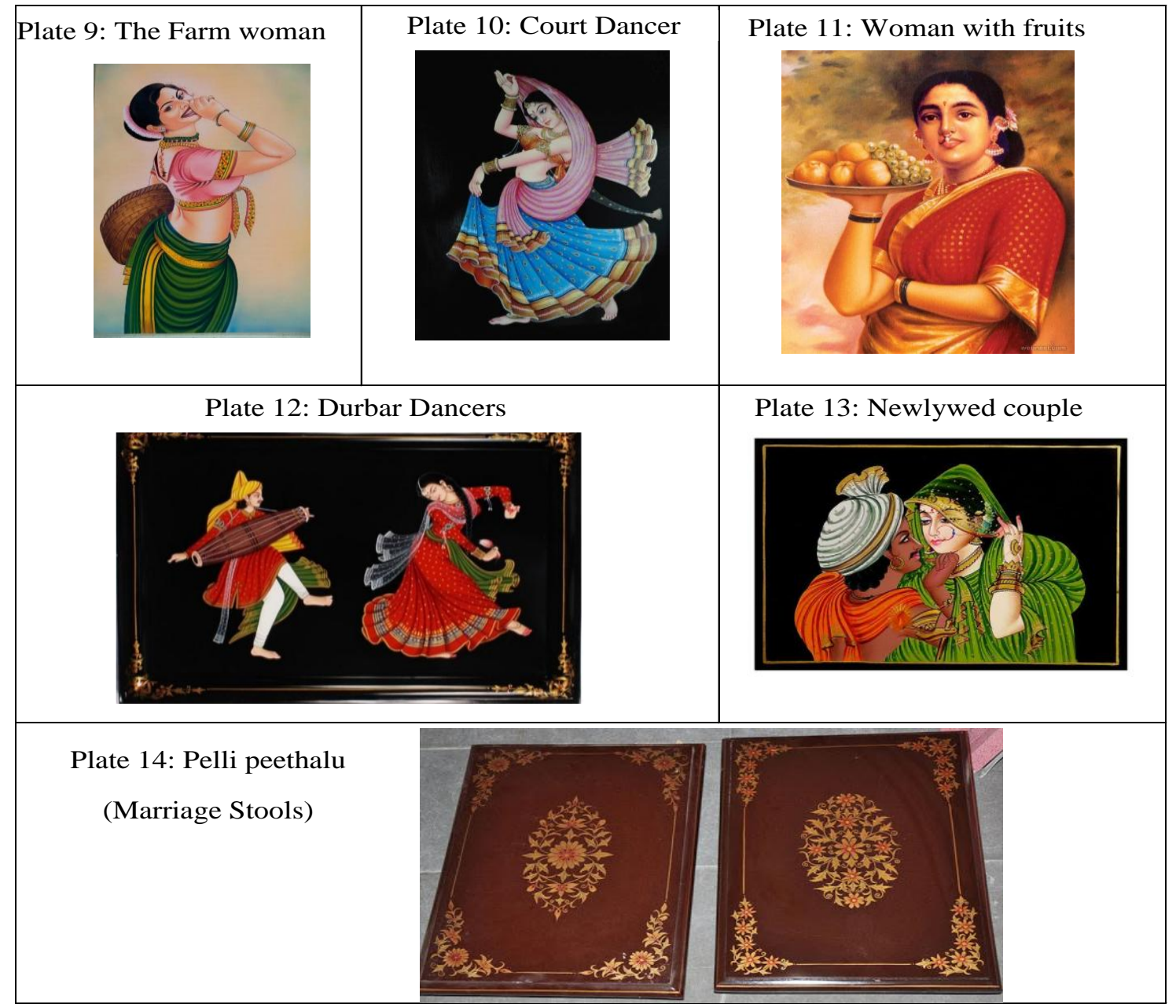

Plate.3

\begin{tabular}{|c|c|c|c|}
\hline Plate 15: The ponniki & $\begin{array}{c}\text { Plate 16: Chintha lappam } \\
\text { coating on the base }\end{array}$ & Plate 17: Polishing the Frame \\
\hline
\end{tabular}




\section{Plate. 4}

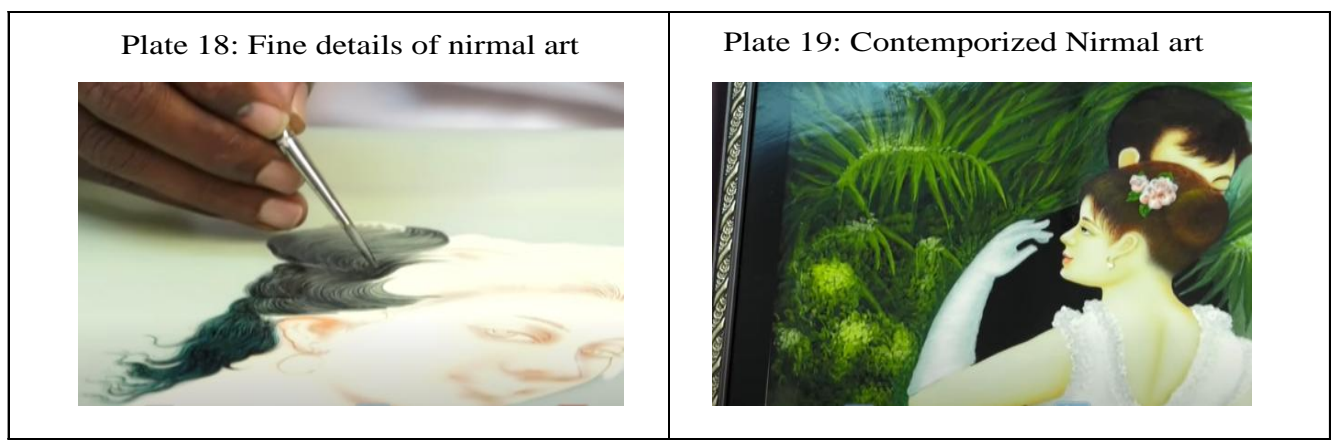

Due to diminishing supply of natural wood and colour sources, nitro-cellulose colours, acrylic paints, deco paints are being replaced on a large scale. These are nowadays available easily with less effort. These synthetic materials have adverse effects on nature, human and environmental health which is of prime concern nowadays. All the above aspects made it clear that Nirmal played a vital role in traditional, cultural, industrial and craft during the Colonial down to the latest modern period. It needs to be preserved and presented to the future generations as a cultural prodigy.

The key features of promoting any handicraft sector is creating new marketing ideas and concepts as per the customer needs. This can be achieved through flexible production system, diverse design base, ability to provide good design base in small and medium volumes, quick switch over to product diversification. The products diversification can be created through using the traditional art with required changes and slight modifications. This can be done through designing new products, redesigning the existing products with changes in shape, size, colour and surface manipulation, function and utility (Cameronand Kenderdine,2007) [1] Exploration of new markets along with revival of lapsed markets can be made an attempt by applying traditional skills to meet new opportunities and challenges. Efficient marketing efforts are considered as critical requirements for the handicraft sector revival. E-marketing has emerged as a new mode with high potential and is popular among youth. The interests of both the producer and consumer has to be considered and promoted in order to achieve an overall growth in the handicraft sector (Development commissioner, Handicrafts-2019) ${ }^{[7]}$.

In conclusion the style of Nirmal painting art was born around temples, forts, palaces and in later times have entered the homes, hotels, offices and other aspects and have grown to the capacity of the modern day's interior decoration and architectural aspects and displaying the special social legacy of classic and traditional heritage These aspects are gaining top priority in context to the recent "make in India" and other localized concepts of product development. to promote Indian aesthetic and ethnic values. The skilled workers of quintessential Naqqashi Nirmal painting art work are considered the pride of Telangana, with their handcrafted creations becoming globally popular. These painted furniture sets are ideal to graceful living and office spaces. The painted furniture received Geographical Indication rights in the year 2009.The Nirmal artists presented many forms to suit the taste of patrons of all times. Changes in demands and consumer 
requirements from past to present, the art took many twists and turns in the timeline and has withstood a lot of threats from modern and contemporary art. In spite of all these factors, Nirmal art provides a good platform for the established designers, budding artisans, trade and business people, interior designers in many fields like fashion, textile, apparel, fashion accessories, stationery, antique arts, leather industry, home furnishing sector and many more. This Nirmal art, if provided a growth opportunity has the capability to stage unlimited innovative, unique design development opportunities and scope for coming generations. There is a prominent local belief that if anyone masters the art of Nirmal painting technique and Naqqashi craft, then one can imbibe the talent of doing any type of drawing and painting methods worldwide.

\section{References}

1.Cameron, F. and Kenderdine, S. 2007. Beyond the cult of the replicant: museums and historical digital objectstraditional concerns, Theorizing digital cultural heritage: a critical discourse, The MIT Press pp: 49-75.

2.Dadiga, S. 2017. Nirmal- a historical cultural craft centre in Telangana: A study, International journal of advanced educational research, ISSN:2455-6157, Nov, 2017, 2(6): 328-332. www.educationjournal.org

3.Government of Andhra Pradesh, Director of handcrafts and handlooms textile report, 1985, Hyderabad.

4.Government of India. Development Commissioner (Handicrafts), Ministry of Textiles, 2001. Report on Task Force on Handicrafts for the 8th Five Year Plan, New Delhi. pp. 15-26.

5.Imperial Gazetteers of India AdilabadNizamabad and Karimnagar, 1908, http://www.burmalibrary.org/docs21/I
mperial_Gazetteer_of_India-Vol.191908-to.pdf

6.India, Assistant Director, Office of the Development Commissioner (Handicrafts), Handicrafts and marketing, Service Extension Centre, Warangal, 1999-2000 report, Present status of the arts \& crafts in Andhra pradesh-Profile of the crafts, pp. 11-32, 176-196

7.India, Regional Director, Office Development Commissioner (Handicrafts) Southern Regional Office, Chennai, 2009-2019 report, State folder of A.P. Handicrafts, pp.1628

8.Isacco, E., and J. A. Darrah. 1993. The ultraviolet and infrared method of analysis. A scientific approach to the study of Indian miniatures. Artibus Asiae, LIII (3/ 4):470-91.

9.Rao, S. K. 2012. Socio-economic analysis of handloom industry in Andhra Pradesh-A study on selected districts, Journal of exclusive management science, September, 2012, 1(8):1-15.

10.Silva, De, 1971, The evolution of the technique of Sinhalese wall paintings and comparison with Indian painting methods, pp: 35-48.

11. Thombare,N, Srivastava,S, Chowdhury, A. R. 2014, Multipurpose applications of tamarind seeds and kernel powder, Science reporter, September issue, pp.32-33.

https://www.researchgate.net/publicati on/306038753

12. Venkateswarlu, G. 2015. A study of traditional paintings in Andhra with reference to Nakashi Kalamkari: Nirmal, Department of Ancient Indian History, Sri Venkateswara University, http://hdl.handle.net/10603/185217

13.https://en.wikipedia.org/wiki/TelanganaDa te of visit: 24-06-2020

14.https://golkondacrafts.telangana.gov.in/, 
Telangana, Date of visit: 28-06-2020 15.http://nirmaltoysandarts.com/

16.http://www.censusindia.gov.in/2011census /dchb/2801_PART_B_DCHB_ADILABA D.pdf

Census of India. The Registrar General \& Census Commissioner. pp. 13, 44. Retrieved 13 May 2016.

17.http://www.telugudictionary.org/telugu_en glish.php?id=9978Date of access: 6-72020 18.https://indiabiodiversity.org/species/show/ 31380

19.https://www.altrafine.com/tamarindkernel-powder 2019

20.Personal Interview with the Artisans and local entrepreneurs, trade people by the research scholar.

21.Visits to Nirmal Toysand Arts Industries Co-operative Society limited, Nirmal

\section{How to cite this article:}

Challa Lakshmi and Manisha Gahlot. 2020. The Quintessential Naqqashi Nirmal Painting Art of Telangana: Source of Inspiration for Innovative Textile Design Ideas. Int.J.Curr.Microbiol.App.Sci. 9(08): 803-814. doi: https://doi.org/10.20546/ijcmas.2020.908.086 